\title{
ELEMENT OF WATER IN KOREAN CULTURE AND GARDEN ART OF KOREA
}

\author{
Natalia A. Bolotova ${ }^{1}$ \\ Rustem R. Muhametzyanov ${ }^{2}$
}

\begin{abstract}
The East always was Korean gardens save their originality and mysterious for Europeans, and it continued till 16-17 centuries. When it comes to the Near East, China, Japan and India, we can see that researches at that time gave a lot of information about these countries, but as for Korea, there was just fragmentary information. More detailed research of Korea has begun much later, that is why there are still a lot get new semantic contents which spread on each element of a park-garden complex. The analyze of evolution of base elements of Korean garden gives us a possibility not only see changes of culture complex, but also helps us to understand a mechanism of interaction of cultures when recipient culture saves its originality and uniqueness.
\end{abstract} of subjects needed be researched. And one of them is Garden Art of Korea. It should be mentioned that researchers telling about Korean gardens give only general things and do not do detailed analyze. This article analyzes an image of water and its realization in the Garden Art of Korea. As we know, Koreans have a special attitude to nature as an object of contemplation and comprehension. And this attitude was incarnated through parks and gardens, which develop under the influence of Chinese culture. But

Keywords: culture of Korea, China, park, water, element of water, Buddhism, Taoism, Orient, nature, dao, Koguryo.

\section{Introduction}

Garden Art of Korea incarnates a harmony with nature in its original state. To Koreans nature is not only source of beauty, but also a source of energy for mind and spirit. Korean

\footnotetext{
${ }^{1}$ Kazan Federal University. e-mail: taeseop@yandex.ru. Tel.: +7871874434.

${ }^{2}$ Kazan Federal University. e-mail: taeseop@yandex.ru. Tel.: +7871874434
} 
people always have been thinking that they are united with nature; they saw themselves as a part of one world, where everything is connected. Moreover, when it comes to archaic culture, they explained natural phenomena through existing of natural spirits; they deified nature and identified its main elements. Identifying of main nature elements it is not only the image of changes in socioeconomic life, but also an indicator of the development of natural philosophy. Water is the one of those identified nature elements. Korean traditional culture identifies water as one of the foundations of the universe.

On the one hand in Korean mythology water is connected with fertility, on the other hand it is connected with formation of civilization and statehood. The formation of the cult of fertility is connected with development of agrarian relations in Korea. Wellbeing of the rural community and the state were depended on water and rain.

In the folk ritual practice, as J. Ionova thinks, the rain is associated with the spirit of water and wind and with the image of a dragon that is Lord of water. Moreover, rain as a natural phenomena and gracious power of reviving water is also an attribute of Heaven [7, P.153]. In this combination of Korean believes features of ancient mythology, shamanism and late culture borrowing from China are connected.

Droughts and floods that are caused by natural reasons aroused a sense of anxiety, uncertainty and desire to prevent future disasters. And to do this people made traditional seasonal and periodic sacrifices to the Heaven, Spirit of rain and water. Frequent droughts and floods and bad harvest caused by it led to consolidation in people's minds that those kinds of sacrifices are necessary.

Within the commune these rituals were carried out by shaman and that strengthened the faith in spirit of water, dragons and miraculous features of water. And it led to formation of folk attitude on element of water.

But when it comes to state the ruler and officials were responsible for this ritual. It was due to two aspects. First aspect is connected with point of view of ancient Korea's period, when natural disasters trough theory of yin-yang and five elements were considered as violation of the harmonious functioning of the universe and people's society [7, pp. 154-155]. To restore the harmony bequeathed by ancestor ritual was needed. The second aspect was 
connected with interpretation of natural disaster as Heaven's anger to actions of a ruler. Therefore the ruler and his officials should periodically perform a ritual in the name of Heaven. On the one hand, to care about citizens and state is part of Confucianism. On the other hand, Korean mythology gives us a basis to say that ruler is related to the Heaven. So in the ancient Korean myth about Dangun, who has established State of Korea on Korean peninsula, tells us how Dangun's father Hwanung with God of the rain goes down from Heaven to Taebaeksan Mountain where holy tree Sindansu was located [6, pp. 32-33]. Moreover if we look through ancient Korean legends we will see that mothers and wives of legendary Kings are appearing from the water. In the legend about Jumong, founder of Goguryeo, his mother Yuhwa was the daughter of Habaek, God of the river, and when she appears in the world she comes out of water [2].

It means that King has prerogative to address to the Supreme with requests and prayers. Also it shows representation of water (ying) as femininity and basic substance for cult of fertility in Korean natural philosophy.

Thus, the image of water has some different representations. On the one hand, it is connected with fertility and folk imagery which were under the influence of shamanism. On the other hand, the element of water is a part of state cult as a carrying for the rain and good harvest. That is to say water has a sacred-religious interpretation. But water as one of the initial elements allows interpreting the image of water through secular beginning. And this image will be fully revealed in the garden art where water will get new meanings thanks to dialogue of Korean and Chinese cultures.

\section{Methods}

Before we will go to results of our research we should tell about methods which were used in it. First of all we should mark that we took the attitude of $\mathrm{A}$. Toynbee, who thinks that dialogue of cultures is one of required conditions for civilization's development, as a basis [1, pp. 530-537].

Also we almost completely agree with A. Toynbee who also thinks that when culture takes one element of other culture after some time it will take the whole complex. But there is also one more aspect that can be questioned. 
There is no mechanism that changes "alien element" to "own element".

In this aspect we rely on $\mathrm{M}$. Bahtin's research that came to the theory of culture dialogue through analysis of problem of "different", and showed how "alien element" can become "own element" [8, pp. 5-7]. But these changes are not full assimilation of "alien" to "own". This "alien element" is alien by its nature, and it just begins to exist as "own alien element". Understanding "own element" and "alien element" is united, but they are not the same. Mastering experience of another culture and understanding mechanism of this process are very important to understanding the whole process of interactions of different cultures.

Moreover our research assumes studying elements of cultural complex. And this studying is based on historical method. That is analysis of element's evolution in its historical development. This method allows us to show not only changes in time, but also to see how it changed with the whole complex through the dialogue of cultures.

\section{Results}


Theory of five Primary

Elements includes conception of yinyang. Yin-tang explains the universe and human phenomenon trough principles of yin (susceptibility, darkness, femininity) and yang (creativity, masculinity, active power) and its cooperating. As for five elements theory, it explains existence trough changes in five elements (wood, fire, earth, metal and water). In Korean garden-park complexes we can see these theories not only in the changing of seasons, but also in main elements of a garden (water - yin, earth - yang etc).

Particular influence on gardenpark complexes of Korea is given by Taoism, in which Koreans saw the same reverent attitude to the world around us. It should be mentioned that Taoism influenced on Garden Art in China too. Garden was a part of Taoist worldview in strictly regulated Confucian social world.

Taoism prescribed to accept nature as it is. And to create gardens with minimized impact on nature. So Koreans let elements of a garden to merge with nature and to prosper. Naturalness which is mentioned by Taoists became the main feature of Korean gardens; where human can learn the great Tao.
By accepting that, Koreans admitted in their culture symbols of Tao and new meaning of garden's natural elements. Here it should be mentioned about pounds in Korean gardens which were made in rectangular form and had a round island in the middle. This composition was based not only on yinyang theory, but also on Taoism where round means Heaven and rectangular means Earth [9]. The favourite symbol of Tao was water [5, P. 52]. And it was not matter in what form it was, surface or flow. Moreover, water as symbol of Tao, meant Changes. Taoists believe that human goal is to know him, to feel the flow and to fit in sequence of changes. As we can see, water plays very important role in Taoists attitude the nature.

Even though Korean gardens tended to big space and visual enjoyment of beauty, their main elements were not flowers, hills or lawns. The main elements of Korean gardens are stone and water. That is why pound is the most important element in Korean garden. But if there was no pound, there was stream or even waterfall. Sometimes we even can see a combination in which stream flows into a lake. As it was in case of Anapji (아납지), that was created in 674 
in Gyeongju. «The waterside is edged by several rows of medium-sized stone blocks everywhere, so water (yin) contacts with earth (yin), trough the stone (yang). The pound is filling by flowing water, which flows at the southwest corner through two-stage waterfall that is made of nine stones» [11, P.148].

The form that water took was depended on the size of a garden, and also on its owner. The most often it was an unnatural rectangular form pond, and there was round form island in the middle of a pond. One special feature of ponds in Korean garden unlike in China is that people could not swim across the pond. There was no boat in the garden. There was no such tradition as swimming across the pond in Korea. Because the island in the middle of a pond could be seen from the harden house and pavilion that is located on island was connected with the waterside by wooden bridge. Ponds were small because Korean could not afford to create big gardens due to natural geographical conditions.

Many gardens were created in picturesque places where mountains and streams were located. So the structure of a garden was determined by topographical conditions and stream's
192

flow. Gardens were classified according to is there a stream of in what direction stream flows. Sometime later streams were classified as "flowing", that crossed the garden, and "along siding", that were on the edge of a garden [12, P.193].

«Along siding» streams flow outside of a garden; they also were classified into: flowing streams, which form was not changed, and still streams, which were used to create an artificial pond in the middle of which an isled was located. Compared to still streams flowing streams were located in the place where water's flow was wide and plentiful. Elements of garden's landscape were consisted of stones of different forms and rocks; Amseojae (암서재), Joganjeong (조간정) и Geoyeonjeong (거연정) are good examples of gardens of that type.

We also can remember gardens of Joseon period as Namganjeongsa (남간정사) and Ongnyugak (옥류각), which are examples of small gardens with streams that flow under the structures with wooden floor. In Namganjeongsa stream is deliberately brought into the garden to create a pond; water also was used to create artificial canal that flowed under the building 
before flowing into the pond. In Ongnyugak pavilion was built above the stream deliberately to maximize feel of aesthetic and romantic atmosphere of surrounding landscape.

During Joseon period Buddhism fades into background and Korean gardens get a new impulse of development. First of all it was due to the thing that garden became a part of Confucian world in Taoist interpretation. It could be seen in the form of a pond, for example. So most ponds (about 70\%) were square, and remaining $30 \%$ were natural. In most gardens square ponds had round form island in the middle. Moreover, garden also transform into place of intellectual leisure. Of course, before that garden was a place to spend time in. So garden in Buddhist temple was used during meditation. In palace gardens royal receptions were performed. Scientists' gardens were places of seeking inspiration, creation of lucubration and paintings. And as it was mentioned, garden was a place of intellectual leisure. In the garden's pavilion people played Baduk, performed tea ceremony. These entire things characterized garden as a place of beauty's contemplation and soul's calming.
But it did not mean that Korean gardens lost Buddhist influence. Favourite plant in the garden is lotus. For example, Biwon, or Secret Garden of Changdeokgung Palace, Aeryeonji pond (애련지) is full of lotus flower during summer. In the ancient period Korean scientists honored lotus flowers because they could blossom in turbid water. In Confucianism lotus flower symbolizes pureness and directness of secular world [4, P. 112]. Thus, in ideological background garden-park complex remains as universal space that can unite all religious and philosophical thoughts.

\section{Discussions}

There are two approaches to Korean culture. The first one claims that Korean culture has no originality and it is just a product of borrowed elements from Chinese and Japanese cultures. Due to this fact researches ignore features of Korean culture [3 P. 78; 10, P. 298]. The second approach is based on other methodological positions that consider each culture as original one. From this point of view Korean culture has its own originality and features.

Also it should be mentioned that researches of Korean culture stick to the typological analyze of culture 
complexes. But they forgot about evolution of elements that culture system are consists of. So we think analyze, that was made in this article, gives a possibility to find answers to a lot of discussion questions.

\section{Summary}

As it was said before, water is one of main elements of a garden. Its presence in the park-garden complex is not accidental. A worship of element of water has begun within archaic religious believes, and at each stage of evolution of Korean history semantic meaning of water were transformed. Although the influence of Chinese culture was strong, traditional Korean attitude to water dominates.

\section{Conclusions}

Korean garden is a garden that was made according to principles of deification of nature. The main goal of such gardens is to be close with nature and its spirits. It means that human intervention in the world of nature and kingdom of spirits should be minimized. It is initial orientations of Korean culture that were maintained by shamanism during long period of time.

Later we can see formation of another attitude to nature. It happens during development of traditional Korean natural philosophy and under the influence of Chinese culture. And all these things affect on Korean traditional garden. Buddhism, Taoism and Confucianism take the place of shamanism. But we should not forget that each borrowed Chinese element was adopted to Korean mentality and changed.

It also has happened to water, the one of main element of natural world. If initially this element was associated with fertility and agriculture, later its role changes. This is due to the fact that water becomes a symbol of Changes which human must comprehend. But at the same time it is also a symbol of Buddha's teachings. It is Water of Truth that helps human to find his place in this world.

Thus, through the image of water in Korean culture we can see all features of Korean culture and also we can understand the system of values that only Koreans have.

\section{Acknowledgements}




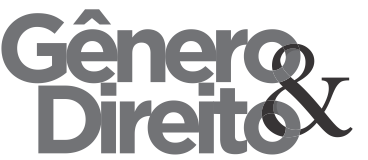

Periódico do Núcleo de Estudos e Pesquisas sobre Gênero e Direito

Centro de Ciências Jurídicas - Universidade Federal da Paraíba V. 8 - No 04 - Ano 2019 - Special Edition ISSN | 2179-7137 | http://periodicos.ufpb.br/ojs2/index.php/ged/index
The work is performed according to the

Russian Government Program of

Competitive Growth of Kazan Federal University.

\section{References}

A. J. Toynbee, "A Study of History”, M., Progress, 736 p., 1991.

B. Kim, Samguk sagi vol. 2, e-version Thietmar, 2006.

Ch. Thacker, "The History of Gardens", University of California Press, 288 p., 1985.

Cultural Heritage. Traditional lifestyles /Korea Foundation, 264 p., 1997.

E. Zavadskaya, "Esteticheskiye problem zhivopisi starogo Kitaya", Aesthetic problems of old China painting, M.: Iskusstvo, 440 p., 1979.

Iryeon, Samguk Yusa, translation Ha T. Yonsei University Press, 417 p., 1972.

J. Ionova, "Etnografiya Korei”, Korean ethnography, M., Pervoe marto, 424 p., 2011.
M. Bahtin, "Estetika slovesnogo tvorchestva", Aesthetics of verbal creativity, M.: Iskusstvo, 424 p., 1979. Sh. Wang. "The influence of Taoism on Korean culture", materials for 1st World Congress of Korean Studies, e-version, 2013.

T. Turner, "Garden History: Philosophy and Design, 2000 BC-2000 AD”, Taylor \& Francis, 445 p., 2005.

V. Belozyorova, "Sady Korei i vzaimodejstviyz dalnevostochnih cultur", Gardens of Korea and interaction of Far Eastern cultures, Iskusstviznaniye №1/01, p. 144-160, 2001.

W. Sim, Y. Kim, J. Choi, S. Shin, Ch. Park, J. Lee, K. Choi, Y. Kim, G. Ahn, K. Hong, S. Lee, H. Kim, D. Jang, H. Hong. Korean Traditional Landscape Architecture. Hollym Corp., p. 472, 2009. 